\title{
Analisis Peningkatan Pendapatan Mahasiswi Dan Ibu Rumah Tangga Di Kelurahan Simpang Baru Dalam Pengolahan Akrilik
}

\author{
HARDI \\ Dosen Tetap Fakultas Ekonomi Universitas Lancang Kuning \\ Jln. Yos Sudarso KM 8 Rumbai \\ E-mail : hardisintong@gmail.com
}

\begin{abstract}
Attempts to improve human resource capacity need to be held in the field of handicraft especially acrylic beads (handmade). The purpose of holding in order to be able to process acrylic beads into various preparations. In addition it is expected that participants can entrepreneurship so as to improve the family economy. This research was conducted in the new simpang pelam village by using the approach of Observation, Interview and Library Studies, and how the impact of improvement for the mother and mother of the stairs and female students. From the results of interviews and questioners who have been distributed and analyzed, it can be concluded most have understood how entrepreneurship and not yet mastered about good marketing, but already understood with entrepreneurship this can be seen from the results of quisioners who have dianalis, housewives and housewives Female students in the new simpang urban village Charming Pekanbaru on housewives and college students began to understand the way of marketing and good entrepreneurship. With the skill and strong desire of the student and the housewife to increase their opinion.
\end{abstract}

Keywords: Entrepreneurship, Marketing, Income Increase

Tujuan pembangunan nasional adalah meningkatkan pendapatan perkapita masyarakat dengan harapan dapat mempercepat realisasi program pengentasan kemiskinan dan perbaikan derajat kesehatan yang pada akhirnya mendatangkan kemakmuran dan kesejahteraan bagi rakyat.

$$
\text { Upaya untuk meningkatkan }
$$

kemampuan SDM perlu diadakannya pelatihan di bidang kerajinan tangan khusunya manik-manik akrilik (handmade). Tujuan diadakannya pelatihan agar peserta mampu mengolah manik-manik akrilik menjadi berbagai macam olahan. Selain itu diharapkan peserta bisa berwirausaha sehingga bisa meningkatkan ekonomi keluarga.

Dalam upaya pengembangan usaha, metode pendekatan yang perlu dilakukan adalah berupa bimbingan pembinaan mutu kepada masyarakat sebagai pelaku usaha mikro dan sekaligus untuk pemanfaatan manik-manik akrilik menjadi berbagai variasi produk yang mempunyai nilai ekonomis guna meningkatkan kesejahteraan keluarga. Disamping itu perlu memberikan informasi mengenai manajemen dan kiat-kiat menuju usaha mandiri berkelanjutan, dan membantu dalam menjalin kerjasama dengan pemasaran produk yang dihasilkan.

Kreasi manik akrilik adalah sebuah usaha keluarga, dimana usaha tersebut bergerak dibidang kerajinan tangan (handmade) yang memiliki bahan berupa manik-manik, bahan tersebut diolah dan dijadikan suatu kerajinan tangan yang nantinya akan menghasilkan produkproduk berbentuk bros, bunga, mainan kunci,dll. Kreasi manik ini pada awalnya adalah kegiatan merangkai dan membentuk manik-manik menjadi sebuah benda yang berbentuk souvenir dan aksesoris lainnya.

Kegiatan merangkai dan membentuk manik-manik tersebut adalah sebagai penyaluran hobi yang ditujukan untuk mengisi waktu luang. Namun ternyata souvenir-souvenir yang dirangkai menarik perhatian beberapa saudara dan kerabat. Karena tertarik dan suka pada produk yang telah dibuat maka para saudara, kerabat, dan kolega tersebut 
mulai memesan beberapa variasi jenis produk dan kombinasi warna dari kerajinan manik-manik tersebut.

Trend perkembangan pasar pada usaha perencanaan bisnis Kreasi Manik dipengaruhi oleh beberapa faktor yaitu pertumbuhan ekonomi, inflasi, pengaruh persaingan industri, selera konsumen dan perubahan perilaku. Pertumbuhan ekonomi atau perubahan dalam tingkat umum dari aktivitas ekonomi. Ketika pertumbuhan ekonomi membaik maka tingkat pendapatan masyarakat akan lebih membaik, sehingga permintaan masyarakat terhadap suatu barang akan lebih tinggi. Berarti trend penjualan akan membaik, maka perusahaan yang menjual produk barang penerimaannya akan lebih tinggi. Bandingakn ketika ekonomi Indonesia terkena krisis, maka daya beli masyarakat menjadi menurun, trend penjualan akan menurun dan akibatnya banyak usaha yang rugi besar pada waktu itu.

Manfaat kewirausahaan ditunjukkan bahwa pemilik bisnis kecil menyakini bahwa mereka bekerja lebih keras, menghasilkan lebih banyak uang, dan merasa lebih bahagia daripada bekerja untuk orang lain atau perusahaan lain. Dalam situasi ekonomi sesulit apapun, wirausaha harus tetap optimis dalam menggeluti bisnisnya. Sebab keberanian wirausaha dalam menggeluti bisnisnya terletak pada optimisme. Dengan tetap optimis maka kita akan terus termotivasi dan cemerlang dalam memanfaatkan peluang bisnis.

Pemasaran merupakan ujung tombak untuk melakukan penngenalan suatu produk. Dalam dunia usaha persaingan yang semangkin ketat, setiap pelaku usaha dituntut agar tetap bertahan hidup dan berkembang. Oleh karena itu seorang pemasar dituntut untuk memahami permasalahan pokok dibidangnya dan menyusun strategi agar dapat mencapai tujuan. Berikut ini beberapa pengertian mengenai pemasaran : (Sunyoto; 2012;)

1. Menurut philip kotler (2008) pemasaran adalah proses sosial dan manajerial dengan mana seseorang atau kelompok memperoleh apa yang mereka butuhkan dan inginkan melalui penciptaan dan pertukaran produk dan nilai.

2. Menurut william J. Stanton (2007) pemasaran adalah suatu sistem total dari kegiatan bisnis yang di rancang untuk merencanakan, menentukan harga, promosi dan mendistribusikan barang-barang yang dapat memuaskan keinginan dan mencapai pasar sasaran serta tujuan perusahaan.

3. Menurut basu swasta DH (2005) pemasaran adalah sistem keseluruhan dari kegiatan usaha yang ditujukan untuk merencanakan, menentukan harga, mempromosikan dan mendistribusikan barang, jasa, ide, kepada pasar sasaran agar dapat mencapai tujuan organisasi, sedangkan menjual adalah ilmu dan seni mempengaruhi pribadi yang dilakukan oleh penjual untuk mengajak orang lain agar bersedia membeli barang atau jasa yang ditawarkan.

Pesaing atau yang sering juga disebut dengan competitor adalah merupakan faktor yang sangat penting dalam menyusun keberhasilan pemasaran. Dalam usaha Kreasi Manik ini kalau dilihat dari analisis pesaingnya yang terdiri dari: Ancaman masuknya pendatang baru, Tingkat rivalitas diantara para pesaing yang ada, Tekanan dari produk pengganti, kekuatan tawar menawar pembeli, dan kekuatan tawar menawar pemasok.

Ancaman masuknya pendatang baru: Pendatang baru dalam industri biasanya dapat mengancam para pesaing yang ada. Karena pendatang baru sering kali membawa kapasiats baru, keinginan untuk merebut pangsa pasar, serta seringkali pula memiliki sumberdaya yang besar. Beberapa hambatan untuk memasuki industri adalah :

p.ISSN: $2407-800 X \quad$ e.ISSN: $2541-4356$ 
a. Skala Ekonomi (Economies of Scale)

b. Difrensiasi Produk (Product Diffrentiation)

c. Persyaratan Modal (Capital Requirement)

d. Biaya Peralihan Pemasok (Switching Cost)

e. Akses ke Saluran Distribusi

f. Kebijakan Pemerintah

Usaha kecil adalah kegiatan ekonomi rakyat yang berskala kecil dan memenuhi kriteria kekayaan atau hasil penjualan tahunan serta kepemilikkannya sebagaimana diatur dalam undang undang ini:

1. Memiliki kekayaan paling banyak Rp. 200.000.000 (dua ratus juta Rupiah)Tidak termasuk tanah dan bangunan tempat usaha.

2. Memilki hasil penjualan tahunan paling banyak Rp. 1000.000.000 (satu milyar rupiah)

3. Milik warga negara Indonesia

4. Berdiri sendiri, bukan merupakan anak perusahaan atau cabang perusahaan yang dimiliki. Dikuasasi atau berafiliasi baik langsung maupun tidak langsung dengan usaha menengah atau usaha besar.

5. Berbentuk usaha orang perseorangan, badan usaha yang tidak berbadan hukum atau badan usaha yang berbadan hukum, termasuk koperasi (UU No. 9; 1995;5)

Kewirausahaan adalah disiplin ilmu yang mempelajari tentang nilai, kemampuan, dari prilaku seseorang dalam mengahadapi tantangan hidup untuk memperoleh peluang dengan berbagai resiko yang mungkin dihadapinya. (Sudayono; Asep Saefullah; 2011;9).

Ada beberapa definisi wirausaha menurut :

1. Pandangan Ahli Ekonomi : Wirausaha adalah orang yang mengkombinasikan faktor faktor produksi seperti sumber daya alam, tenaga kerja, material, dan peralatan lain untuk meningkatkan nilai sehingga menjadi lebih tinggi dari sebelumnya.

2. Pandangan pelaku bisnis: pelopor dalam bisnis , Inovator, penanggung resiko yang mempunyai visi, kedepan, dan memiliki keunggulan dalam prestasi dibidang usaha.

3. Pandangan Psikolog : Wirausaha adalah orang yang memiliki dorongan kekuatan dari dalam diri untuk memperoleh suatu tujuan serta suka bereksperimenuntuk menampilkan kebebasan dirinya diluar kekuasaaan orang lain.

Semangat kewirausahaan yang perlu dibudayakan antara lain :

1. Kemauan kuat untuk berkarya (utamanya dibidang ekonomi) dengan semangat mandiri

2. Mampu membuat keputusan yang tepat dan berani mengambil resiko

3. Kreatif dan inovatif

4. Tekun, teliti, dan produktif

5. Berkarya dengan semangat kebersamaan dan etika bisnis yang sehat

Berdasarkan kelima semangat kewirausahaan tersebut maka jelas bahwa yang dibutuhkan oleh seorang pengusaha atau wirausaha adalah berkarya dengan semangat mandiri yang disertai dengan semangat kebersamaan dan kekeluargaan . Hal ini menunjukkan bahwa wirausaha hanya memikirkan bisnisnya sendiri, melainkan juga dituntut untuk memperhatikan bisnis orang lain. Dengan kata lain, tidak boleh saling menjatuhkan, terutama pada bisnis sejenis. Persaingan harus dilakukan secara sehat agar mendorong munculnya wirausaha wirausaha baru yang tangguh, kreatif, inovatif, produktif namun tetap menjaga karakter bangsa Indonesia yang ramah, bergotong royong persaudaraan sejati, dan tidak melanggar etika bisnis.

$$
\text { Wirausahawan (Enterpreneur) }
$$
adalah seseorang yang mengorganisasikan, mengoperasikan dan memperhitungkan resiko untuk sebuah 
usaha yang mendatangkan laba. Seorang pelaku usaha telah melakukan pengorganisasian terhadap sumber daya yang dimilikinya dalam ruang dan dimensi yang terbatas dan berusaha mengoperasikan sebagai kegiatan usaha guna mencapai laba. Dalam mengorganisasikan dan mengoperasikan usaha tersebut, pasti berhadapan dengan sejumlah resiko, utamanya resiko kegagalan.(Mulyadi Nitisusastro;2009;27)

Agar efektif, seorang pemimpin perusahaan kecil harus melakukan tugas tugas yang sangat penting, termasuk yang berikut ini:

a. Menerima karyawan yang tepat dan selalu berusaha memeprbaiki kemampuan mereka.

b. Membangun budaya untuk mempertahankan karyawan

c. Merencanakan "penyerahan estafet" ke generasi kepemimpinan yang berikutnya. (Thomas w. Zimmerer, alih bahasa Deny Arnos Kwary; 2009; 412)

Wirausahawan adalah Seseorang yang menciptakan bisnis baru dengan mengambil risiko dan ketidakpastian demi mencapai keuntungan dan pertumbuhan dengan cara mengidentifikasi berbagai peluang penting dan menggabungkan sumber daya yang diperlukan untuk mengoptimalisasikan sumber daya sumber daya itu. (Thomas W. Zimmerer, alih bahasa Deny Arnoa Kwary;2009;6). Berikut ini ciri ciri untuk mencapai sukses mengenai profil wirausahawan :

1. Hasrat akan tanggung jawab

2. Lebih menyukai resiko menengah

3. Menyakini kemampuannya untuk sukses

4. Hasrat untuk mendapatkan umpan balik yang sifatnya segera

5. Tingkat energi yang tinggi

6. Orientasi masa depan

7. Ketrampilan mengorangisasi

8. Menilai prestasi lebih tinggi daripada uang

\section{METODE}

Metode penelitian dengan menggunakan teknik survey, Populasi dalam penelitian ini mengabil 40 responden. Sedangkan sampel yang digunakan dalam penelitian ini adalah ibubu dan mahasiswa yang tinggal di Kelurahan simpang baru Tamapan Kota Pekanbaru, yang dipilih dengan menggunakan metode Purposive Sampling. Teknik pengumpulan data dengan kuesioner dan teknik analisis data deskriptif kualitatif, merupakan suatu teknik yang menggambarkan dan menginterpretasikan arti data-data yang telah terkumpul dengan memberikan perhatian dan merekam sebanyak mungkin aspek situasi yang diteliti pasa saat itu, sehingga memperoleh gambaran secara umum dan menyeluruh tentang keadaan sebenarnya, dengan tujuan membuat deskripsi, gambaran atau lukisan secara sistematis, factual dan akurat mengenai fakta-fakta, sifat-sifat serta hubungan antar fenomena yang diteliti (Nazir, 2003).

\section{HASIL}

Pelaksanaan penelitian ini dilakukan di Kecamatan Tampan Kelurahan Simpang Baru RT 02 RW 06 Kota Pekanbaru Riau dengan responden mahasiswi dan Ibu rumah tangga. Penelitian ini dilaksanakan pada tahun 2016. Yang menjadi responden adalah Mahasiswi dan ibu rumah tangga di kelurahan Simpang Baru Kecamatan Tampan Kota Pekanbaru.

Adapun peserta ibu rumah tangga kebanyakan dari mereka hanya sebagai ibu rumah tangga dan cuma sedikit yang bekerja dikantor, sedangkan kelompok mahasiswi adalah mahasiswi yang kuliah Universitas Sultan Syarif Kasim Riau. Jumlah responden yang diteliti sebanyak 20 orang mahasiswi dan 20 orang ibu-ibu RT.02 RW.06. Dari harapan tersebut ternyata semuannya terpenuhi, jumlah peserta yang hadir berjumlah 40 orang. Kelompok mahasiswi sebanyak 20 orang dan kemmpok ibu rumah tangga sebanyak 20 orang yang bisa mengikuti kegiatan. 
Dari hasil wawancara dan Quesioner yang telah didistribuskan dan dianalisis, dapat disimpulkan bahwa responden sebagian besar sudah memahami bagaimana berwirausaha tetapi belum begitu menguasai tentang pemasaran yang baik, tetapi sudah mengerti dengan kewirausahaan hal ini dapat dilihat dari hasil quisioner yang telah disis oleh ibu-ibu rumah tanga dan mahasiswi di kelurahan simpang baru tampan Kota Pekanbaru Pada dasarnya para ibu-ibu rumah tangga dan mahasiswi mulai memahami bagaimana cara pemasaran dan kewirausahaan yang baik. bahwa dengan kemampuan skill dan keinginan kuat dari Mahasiswi dan ibu-ibu rumah tangga tersebut.

\section{PEMBAHASAN}

Peningkatan pengetahuan atau kiatkiat membangkitkan usaha rumahan dan mandiri atau kewirausahaan dan pemasaran produk bagi Kelompok Mahasiswi dan Kelompok ibu-ibu RT.02 RW.06, adalah merupakan bagian yang sangat penting dan harus diketahui oleh para responden untuk menuju menjadi usaha mandiri yang sukses dan berhasil. Memulai usaha memang sungguh luar biasa sulit, tidak hanya diperlukan modal, tetapi juga tekad, ketrampilan, pengetahuan, ketekunan, berani mengambil resiko, tidak putus asa, pandai mengelola dan kemauan untuk terus belajar. Keterbatasan pengetahuan dan pemahaman responden dalam kewirausahaan dan pemasaran produk memang tidak mudah untuk dilaksanakan.

Dalam penelitian ini dengan cara menyebarkan quisioner dan wawancara langsung. Adapun untuk mengetahui analisis pengetahuan dan pemahaman tentang kewirausahaan dan pemasaran produk, dapat dilihat dari pertanyaan yang telah dijawab melalui baik melalui waancara maupun quesioner yang telah disebarkan, sebanyak 40 responden 20 ibu-ibu rumah tangga dan Mahasiswi sebanyak 20 responden yang belum begitu memahami bagaimana berwirauasa dan memasatkan produk dari bahan akrilik.
Selanjutnya untuk mengetahui para peserta sudah pernah atau belum mendapatkan pengetahuan tentang Pemasaran Produk, dapat diketahui jawaban responden sebelum mendapatkan pembekalan Kewirausahan Dan Pemasaran Produk Hasil Olahan Mahasiswi dan Ibu Rumah Tangga Di Kelurahan Simpang Baru Kecamatan Tampan Kota Pekanbaru bahwa sebayak 20 responden belum begitu memahami bagaimana mencari tambahan pendapatan dari membuat handmade berbahan akrilik. Dengan demikian sebagian besar peserta responden belum pernah mendapatkan pemahaman tentang Pemasaran produk, dan sebagian peserta mengatakan bahwa pemahaman tentang Pemasaran produk tersebut ini baru mereka dapatkan.

Dalam peneltian ini dengan cara menyebarkan quisioner dan wawancara. Adapun untuk mengetahui pengetahuan dan pemahaman tentang kewirausahaan dan pemasaran produk bahwa jawaban responden menunjukkan $90 \%$ peatihan kewirausahaan dan pemasaran produk hasil olahan sendiri sangat diperlukan untuk meningkatan pendapatan baiksebagai ibu rumah tangga maupu sebagai mahasiswi.

Selanjutnya untuk mengetahui para responden sudah pernah atau belum mendapatkan pengetahuan dapat diketahui jawaban responden $100 \%$ belum pernahnya mendapat pemahaman tentang pernah tidaknya mendapatkan pengetahuan tentang Pemasaran Produk yang telah dihasilkan oleh Mahasiswi dan Ibu Rumah Tangga Di Kelurahan Simpang Baru Kecamatan Tampan Kota Pekanbaru bahwa responden yang menjawab belum yaitu semua responden. Ini menjadi perhatian bahwasanya perlunya pelatihan dan motivasi untuk pengetahuan untuk pemasaran produk yang telah dihasilkan

Untuk mengetahui pemahaman tentang puas atau tidaknya produk yang dihasilkan dapat diketahui tentang puas atau tidaknya produk yang dihasilkan oleh responden ternyata seimbang yaitu 50\% mengatakan bahwa mereka puas atas

p.ISSN: $2407-800 X \quad$ e.ISSN: 2541-4356 
produk yang merreka hasilkan dan 50\% lagi belum puas atas produk yang telah dihasilkan, banyak separuh responden belum begitu mahir dalam pembuatan akrilik sehingga hasil yang didapat belum sesuai dengan yang diharapakan oleh para ibu-ibu rumah tangga dan mahasiwi, akan tetapi ini perlu pelatihan ketermpilan dalam pembuatan kerajinan dari bahan akrilik sehinga bisa menopang pendapatan bagi ibuibu rumah tangga dan mahasiswi.

\section{SIMPULAN}

Berdasarkan hasil penelitian dapat disimpulkan bahwa 50 persen ibu-ibu rumah tangga dan mahasiwi dan ibu-ibu rumah tanga kelurahan simpnag baru belum tersentuh dengan pemasaran produk dan kewirausaan yang terbuat dari Akrilik. Para ibu-ibu rumah tangga dan mahasiswi belum begitu terbiasa dengan kewirausahaan dan Pemasaran Produk, dan banyak yang belum memahami arti pentingnya keahlian yang dimiliki untuk dapat membuka peluang agar dapat usaha mandiri. Perlunya pelatihan dan motivasi dalam pembuatan kerajinan dari bahan akrilik.

\section{DAFTAR RUJUKAN}

Abdullah Abiding, SE, 2013, Jurnal Koperasi dan UMKM, Universitas Hasanuddin, www.bimakab.go.id

Asep Saefullah, 2011, Kewirausahaan, Penerbit andi Yogyakarta

Assauri, Sofjan. 2010. Manajemen Pemasaran. Jakarta. Penerbit: PT. Raja Grafindo Persada.

H. Moko. P. Asta Moen, 2008, Entrepreneurship, penerbit Alfabeta,

Indah Ratnaningsih, 2010, 99 bisnis, penerbit Penebar Pew, Jakarta

Kasmir, 2006, kewirausahaan, Penerbit PT. Raja Grafindo Persada Jakarta
Kotler, Philip. Amstrong, Gary. 2008. Prinsip-prinsip Pemasaran. Jakarta. Penerbit: PT. Gelora Aksara Pratama.

Martin Perry, 2002, Mengembangkan usaha kecil, penerbit PT. Rajagrafindo Persada, Jakarta

Sugiarto, 2007, Undang undang dan peraturan tentang usaha kecil dan menengah, penerbit Visi Media, Jakarta.

Sawstha, Basu. 2009. Azas-azas Marketing. Yogyakarta. Penerbit: Liberty.

Sunyoto, Danang. 2012. Dasar-dasar Manajemen Pemasaran-Konsep, Strategi dan Kasus. Yogyakarta. Penerbit: CAPS

Thomas W. Zimmerer, Norman M. Scarborough, 2008, kewirausahaan dan manajemen usaha kecil, edisi 5 buku 2, penerbit Salemba Empat Bandung 